Tomasz Blachowicz', Tobias Böhm², Jacek Grzybowski1 , Krzysztof Domino33, Andrea Ehrmann²

1 Silesian University of Technology, Institute of Physics - Centre for Science and Education, 44-100 Gliwice, Poland

2 Bielefeld University of Applied Sciences, Faculty of Engineering and Mathematics, 33619 Bielefeld, Germany

${ }^{3}$ Institute of Theoretical and Applied Informatics, Polish Academy of Sciences, 44-100 Gliwice, Poland

\title{
Analysis of AFM images of Nanofibre Mats for Automated Processing
}

Analiza slik AFM nanovlaknatih kopren za samodejno obdelavo

\author{
Original scientific article//zvirni znanstveni članek
}

Received/Prispelo 4-2020 • Accepted/Sprejeto 5-2020

\begin{abstract}
The image processing of pictures from fibres and fibrous materials facilitates the investigation of diverse geometrical properties, such as yarn hairiness, fibre bifurcations or fibre lengths and diameters. Such irregular sample sets are naturally suitable to the statistical examination of images, using a random-walk algorithm. This results in the calculation of the so-called Hurst exponent, which is the asymptotic scaling exponent of the mean squared displacement of the walker's position. Previous investigations have proven the appropriateness of this method for examinations of different fibres, yarns and textile fabrics. In a recent study, we used AFM (atomic force microscopy) images, split into different greyscales, to analyse and quantify differences between various nanofibre mats created from polyacrylonitrile. In addition to the strong influence of the nanofibre diameters, a certain impact of the AFM settings was also seen and must be taken into account in future research.

Keywords: electrospinning, polyacrylonitrile (PAN), nanofibrous mat, atomic force microscopy (AFM), Hurst exponent, random walk
\end{abstract}

\section{Izvleček}

Obdelava slik vlaken in vlaknastih materialov omogoča raziskovanje različnih geometrijskih lastnosti, kot so kosmatost preje, bifurkacija vlaken ali dolžine in premera vlaken. Takšni vzorčni seti z nepravilnostmi so naravno primerni za statistični pregled slik z algoritmom slučajnega hoda. Pri tem izračunamo ti. Hurstov eksponent, ki je asimptotični skalirni eksponent srednjega kvadratnega premika položaja sprehajalca. Dosedanje raziskave so dokazale ustreznost metode za oceno različnih vlaken, prej in ploskovnih tekstilij. V nedavni študiji smo uporabili slike AFM (mikroskopije na atomsko silo), razdeljene glede na različne sive odtenke, za analizo in količinsko določitev razlik med različnimi nanovlaknatimi koprenami iz poliakrilonitrila. Poleg močnega vpliva premera nanovlaken je bil viden tudi določen vpliv nastavitev AFM, ki jih je potrebno upoštevati v prihodnjih raziskavah.

Ključne besede: elektropredenje, poliakrilonitril (PAN), nanovlaknata koprena, mikroskop na atomsko silo (AFM), Hurstov eksponent, slučajni hod

Corresponding author/Korespondenčna avtorica:

Prof. Dr. Dr. Andrea Ehrmann

E-mail: andrea.ehrmann@fh-bielefeld

ORCID: 0000-0003-0695-3905
Tekstilec, 2020, 63(2), 104-112

DOI: 10.14502/Tekstilec2020.63.104-112 


\section{Introduction}

Electrospinning can be used to prepare nanofibres or nanofibrous mats from diverse polymers or polymer blends [1-5], even in combination with metallic [6-8], semiconducting [9-11] or other nanoparticles. Subsequent thermal treatment can be used to stabilise the nanofibrous mats chemically [12-14], followed by carbonisation [15-17], or to use a calcination step instead to evaporate the polymer and sinter the residual inorganic material $[9,14,18]$.

To describe such electrospun nanofibres or nanofibrous mats quantitatively, usually the fibre diameter distribution is given $[19,20]$, as well as the fibre orientation $[21,22]$. There are, however, many more interesting parameters, e.g. the pore size or general porosity, which is sometimes measured by sophisticated instruments [23, 24], but hard to define from a microscopic image, even if the resolution is high enough. Such questions are also important, particularly for the application of such nanofibrous mats as filters [25, 26]. Using only high-resolution images as the basis for a quantitative description of a nanofibre mat may be possible by different mathematical methods. Some of them are the fractal dimension, which is often used as an indicator of the roughness of surface coatings or finishings [27] or for the detection of irregularities in the form of fabric defects [28-31], including the topothesy fractal dimension, which is less affected by scale variations and thus assumed to be a good instrument to measure surface roughness [32-34]. Other methods are calculations of the lacunarity, which describes spatial features of multifractal or non-fractal surfaces [35-37], or sometimes the succolarity, which measures the degree of percolation of an image $[38,39]$. Another parameter that can be used is the so-called Hurst exponent. This value is calculated by performing random walks on the parts of an image where the sample is visible. This is how spatially adjacent areas of a sample in a certain image are defined. Hurst exponent evaluations of textile fabrics were performed by our group [40-42] and several other researchers [43].

In our previous investigations, we concentrated on microscopic images of knitted fabrics to evaluate fabric hairiness. This article presents a study of atomic force microscopy (AFM) images taken on different electrospun nanofibre mats, focusing mainly on the influence of the AFM control parameters on the resulting image and the corresponding Hurst exponents.

\section{Materials and methods}

\section{Sample preparation}

A needleless Nanospider Lab electrospinning machine (Elmarco Ltd., Liberec, Czech Republic) was used for sample preparation. The following spinning parameters were chosen: voltage of $80 \mathrm{kV}$ (or $65 \mathrm{kV}$ ), nozzle diameter of $0.9 \mathrm{~mm}$ (or $1.5 \mathrm{~mm}$ ), carriage speed of $200 \mathrm{~mm} / \mathrm{s}$, bottom electrode/substrate distance of $240 \mathrm{~mm}$, ground electrode/substrate distance of $50 \mathrm{~mm}$, chamber temperature of $22^{\circ} \mathrm{C}$, and relative humidity in the chamber of $32 \%$. Electrospinning was performed using a polypropylene (PP) nonwoven as a substrate. The spinning solution contained $16 \%$ (or 20\%) PAN (X-PAN, Dralon $\mathrm{GmbH}$, Lingen, Germany), dissolved in dimethyl sulfoxide (DMSO, min. 99.9\%, S3 Chemicals, Bad Oeynhausen, Germany).

\section{Measurements}

Investigations of the sample morphology were performed with an atomic force microscope (AFM, FlexAFM by Nanosurf, Liestal, Switzerland), using SHR 300 and TAP190Al-G AFM probes as cantilevers, which work in dynamic mode and have tip diameters of $1 \mathrm{~nm}$ and $20 \mathrm{~nm}$, respectively. The AFM settings (proportional (P), integral (I), differential (D) control and setpoint) were either optimised to get a sharp image or, in the second part of the study, varied around the optimum. While P, I and D describe the values of a common PID controller, the setpoint defines the oscillation amplitude of the cantilever in the dynamic mode.

\section{Random walk and Hurst exponent}

In the simplest case, a colour image or, in the case of an AFM image, a greyscale image has to be transferred into a black-and-white image. Often the black parts define the sample area, while the white parts define the pores or the open areas between sample parts, e.g. between the yarns of a knitted fabric [40-42]. The black area can be more or less connected, depending on the sample under examination, starting from a completely black square as one extremum to tiny black spots as another extremum. Next, a so-called random walk is performed on the black parts of the sample only. A random walk can be described as follows: an arbitrary pixel inside the black part of the sample is chosen. Then, a step in an arbitrary direction - one pixel left, right, up or 
down - is performed, followed by another arbitrary step, etc. Finally, after a defined number of steps e.g. $100,1,000$ or 10,000 - the distance between the original pixel and the final pixel (the displacement vector) is calculated.

If this process is repeated several times, the average displacement vector vanishes, since the final pixel will sometimes be located on the upper left of the original pixel, sometimes on the lower right, etc. What does not vanish, however, is the squared displacement vector. For a completely black square, i.e. a large area without any restrictions of the random walk path, the squared average displacement vector can be assumed to be proportional to the number of experiments $n$ :

$$
<\Delta r^{2}>=C n
$$

with the displacement $r$ and a constant $\mathrm{C}$, which is only necessary for mathematical reasons and has no physical relevance.

This formula must be modified as follows for a not completely black area, but rather a complex image with partly black areas, on which the random walk can be performed, and white areas that limit the possible walk directions, especially in fine black structures whose border must not be crossed:

$$
<\Delta r^{2}>=C n^{2 h}
$$

where $h$ represents the aforementioned Hurst exponent (see for example [46] for some mathematical justifications).

Comparing both formulas, we see that for a completely black area $h$ can be expected to be approximately 0.5 to make both formulas identical. For a fractured black area, the possible ways of the random walk are limited by the white areas in between, making the possible distance between the starting and ending points smaller and thus reducing $h$. Indeed, the values of $h$ are reduced for smaller structures, especially for the aforementioned small black dots in a white matrix that do not allow for moving from one black dot to another, thus strongly limiting possible movements.

Such a random walk would result in a single value of the Hurst exponent. Since this is a statistical method, it makes sense to use more than one test. Typically, approximately $100-1,000$ starting points on a given image are chosen on which random walks with $100,10,000$ or $1,000,000$ steps are performed. In this way, a large number of Hurst exponents is calculated, resulting in a Hurst exponent distribution being characteristic for an image, as will be shown in the next section.

It should be mentioned that in this description we started by transforming an original image into a single black-and-white representation. This may, however, not always be sufficient. Here we will also discuss the possibility of splitting one original image into several grey-channel sub-images, for example, labelled with numbers between 0 (black) and 31 (white) representing 256 grey channels. Importantly, this is analogous to the analysis of multi-colour (multi-spectral) or hyper-spectral images, where various wavelengths are split into spectral channels. It is worth mentioning that other image processing methods were not used as pretreatments of the AFM images. To exclude the possible influence of typical AFM image processing routines, using dedicated optimisation software, the original AFM images with line fit applied were used as the basis of this study. The influence of image processing with specific AFM software, especially for sharpening purposes, will be investigated in a future study.

\section{Results and discussion}

Figure 1 depicts an exemplary Hurst exponent distribution measured for a PAN nanofibre mat electrospun with a voltage of $65 \mathrm{kV}$. The area of investigation, as depicted in the orange inset, has a dimension of $25 \mu \mathrm{m} \times 25 \mu \mathrm{m}$. The second image shows the corresponding black-and-white image.

The relatively large Hurst exponent of $h \sim 0.43$ can be attributed to relatively large fibre areas, here defined as the white areas, while the black areas are correlated with borders between neighbouring fibres so that their evaluation would not be related to a physically meaningful property.

This number alone is not very meaningful, so we next tested how strongly Hurst exponents vary for completely different treatments. Figure 2 illustrates a surface showing broken polishing lines on a metallic coating (Figure 2a), as well as a lithography resist (Figure $2 \mathrm{~b}$ ) on atomically smooth substrates. The Hurst exponent distribution on the dark features in Figure 2a results in a smaller Hurst exponent due to the much narrower and additionally 
fractured lines, but only with a small difference to the nanofibre image (Figure 1).

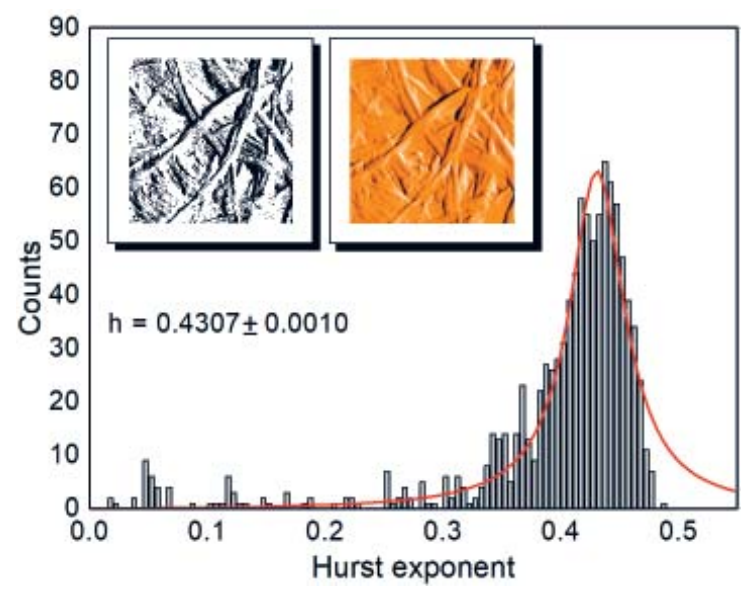

Figure 1: Hurst exponent distribution measured for a PAN nanofibre mat electrospun with a voltage of $65 \mathrm{kV}$, using a nozzle diameter of $0.9 \mathrm{~mm}$ and a polymer solution with 16\% PAN. The insets show the original AFM amplitude image with line fit applied (orange), as well as the corresponding black-and-white image on whose white areas the Hurst exponent evaluation was performed. The red line is the Lorentz line fit to the distribution.

The Hurst exponent distribution calculated for the lithography resist (Figure 2b), on the other hand, shows large connected areas and thus suggests a larger Hurst exponent, which is clearly the case.

The standard deviations (cf. insets in Figures 1 and 2) are very small, as derived from Lorentz line fits to the obtained histograms, which are not symmetrical

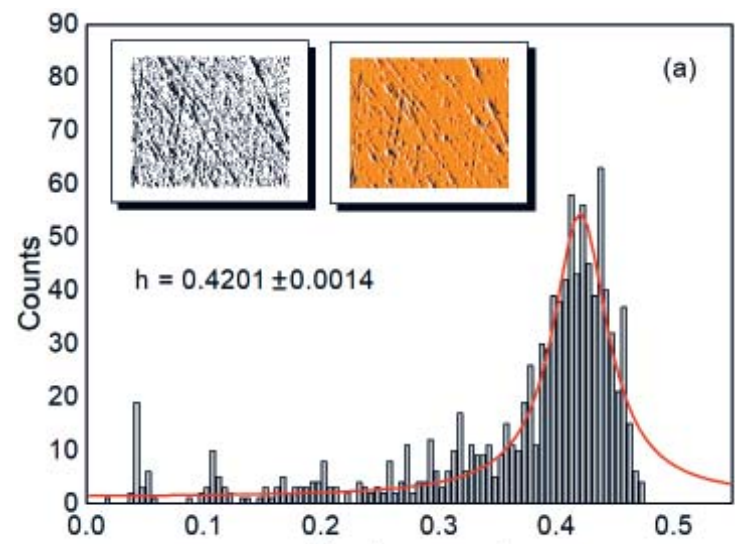

a)

Hurst exponent
(non-Gaussian), since cases $h>0.5$ are not expected in image processing analysis of this type. Thus, the presented results differ and allow for a quantitative differentiation between the different images. Nevertheless, the differences, especially between the nanofibre mat depicted in Figure 1 and the scratched substrate in Figure 2a, are not very clear due to the non-Gaussian character of the distributed data.

Figure 3 shows the results of a Hurst evaluation of another PAN nanofibre mat, this time produced with 20\% PAN dissolved in DMSO, electrospun with a nozzle diameter of $1.5 \mathrm{~mm}$ using a voltage of $65 \mathrm{kV}$ to obtain significantly thicker fibres, as visible

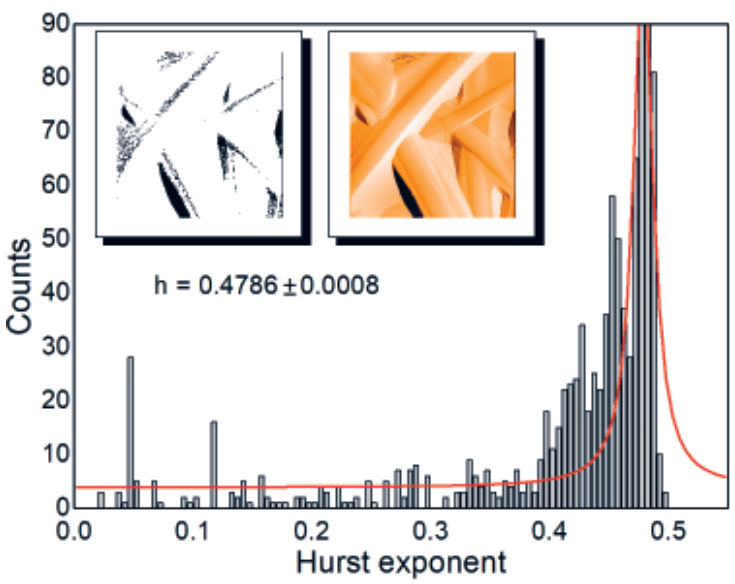

Figure 3: Hurst exponent distribution measured for a PAN nanofibre mat electrospun at $65 \mathrm{kV}$ with $20 \%$ PAN through a nozzle of diameter $1.5 \mathrm{~mm}$. The insets show the original AFM amplitude image with line fit applied (orange), as well as the corresponding blackand-white image on whose white areas the Hurst exponent evaluation was performed.

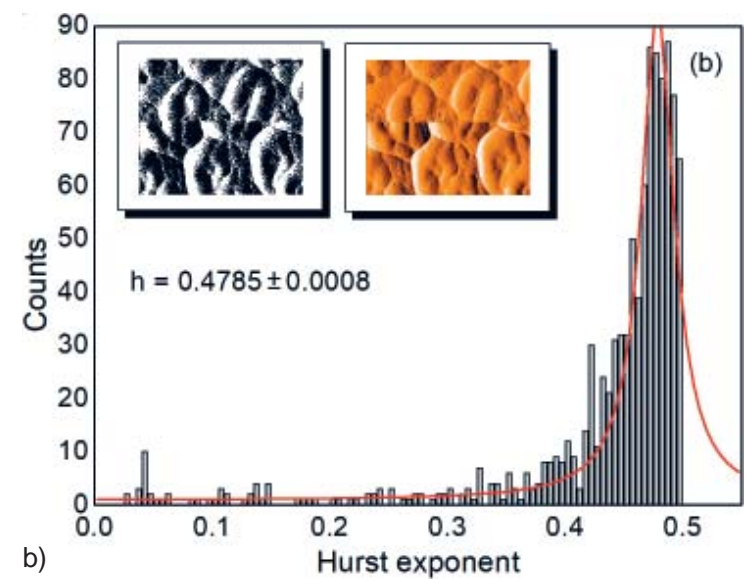

Figure 2: Hurst exponent distributions for (a) a substrate coated with Co and CoO thin films [44] and (b) positive lithography resist on a wafer [45] 

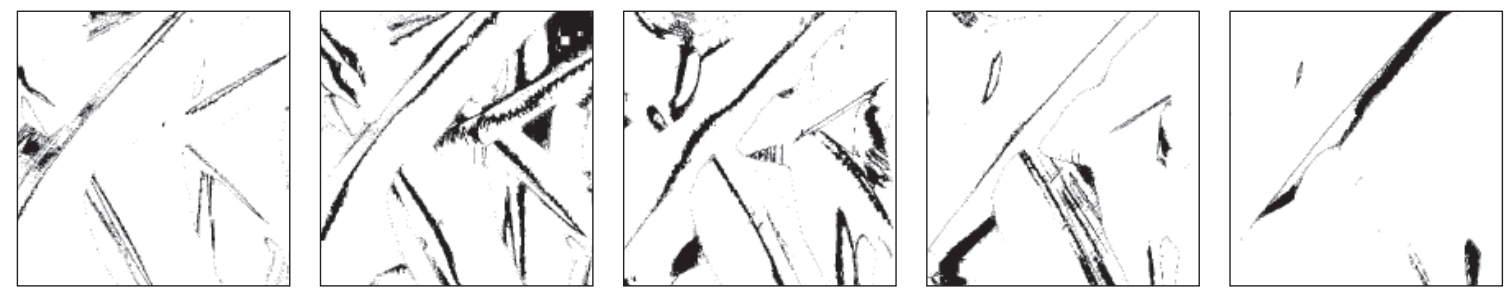

Figure 4: Exemplary greyscale images in which black areas mark defined greyscale levels derived from the AFM image in Figure 3

in the inset image. Indeed, the Hurst exponent distribution of the white areas shows a clear difference to the one presented in Figure 1, which could be expected from the larger fibre areas. Nevertheless, the difference is less well visible than expected. In addition, the average Hurst exponent and standard deviation are nearly identical with those found in Figure $2 b$. This raises the question as to whether the Hurst exponent investigation can be expanded to obtain more information from a given image.

This is why in the next part of the study, the original AFM images were split into 32 sub-images, each containing eight grey levels, so that the whole greyscale from $0-255$ was reduced to 32 sub-images. Figure 4 depicts a few of them, derived from the original AFM image given in Figure 3.

To depict the Hurst exponent distribution for a set of 32 sub-images, it would be necessary to show 32 histograms or alternatively one false-colour image. The false-colour images for the not empty greyscale channels of both nanofibre mat AFM images (Figure 1 and Figure 3, respectively) are shown in Figure 5. Here, white areas show zero counts; small numbers of counts are represented by pink/lilac/blue colours, while orange/red describes large counts.

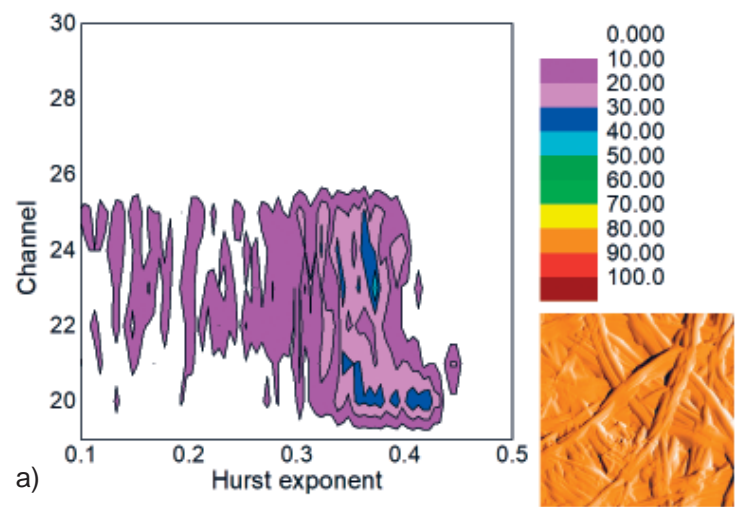

Contrary to the previously shown single-scale Hurst exponent distributions, the differences between both multi-greyscale evaluations are clearly visible here. In both figures, there are areas with low Hurst exponents that seem to be separable and may represent some sort of small targets or artefacts on the original picture. Apparently, this method is also promising for providing a quantitative measure for AFM images of nanofibrous mats, as was shown earlier for knitted fabrics.

Here, however, we must address one problem that does not occur in common optical microscopic methods. As described in the section Materials and Methods, taking AFM images always necessitates the optimisation of typically four parameters, i.e. P, I, D and the setpoint. This optimisation is based on the experience and the personal preferences of the experimenter, i.e. it is to a large degree subjective.

Images were thus taken with P-values of 350,450 , 550, 650 and 750, I-values of 600, 900, 1,000, 1,100, and setpoints of $45 \%$ and $60 \%$, while the D-value was kept constant here due to its small impact on the resulting images. Generally, changing the parameters resulted in shifting certain areas to other greyscale levels (not shown here), if evaluations

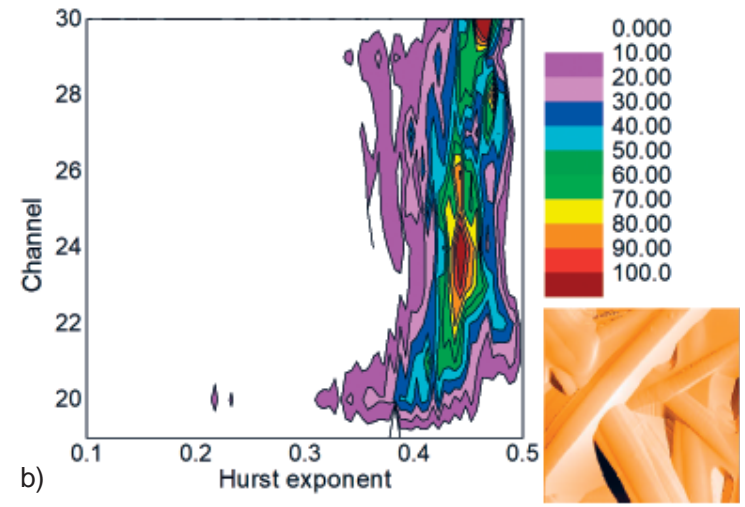

Figure 5: False-colour images of greyscale dependent Hurst exponent distributions obtained through the evaluation of inset AFM images 

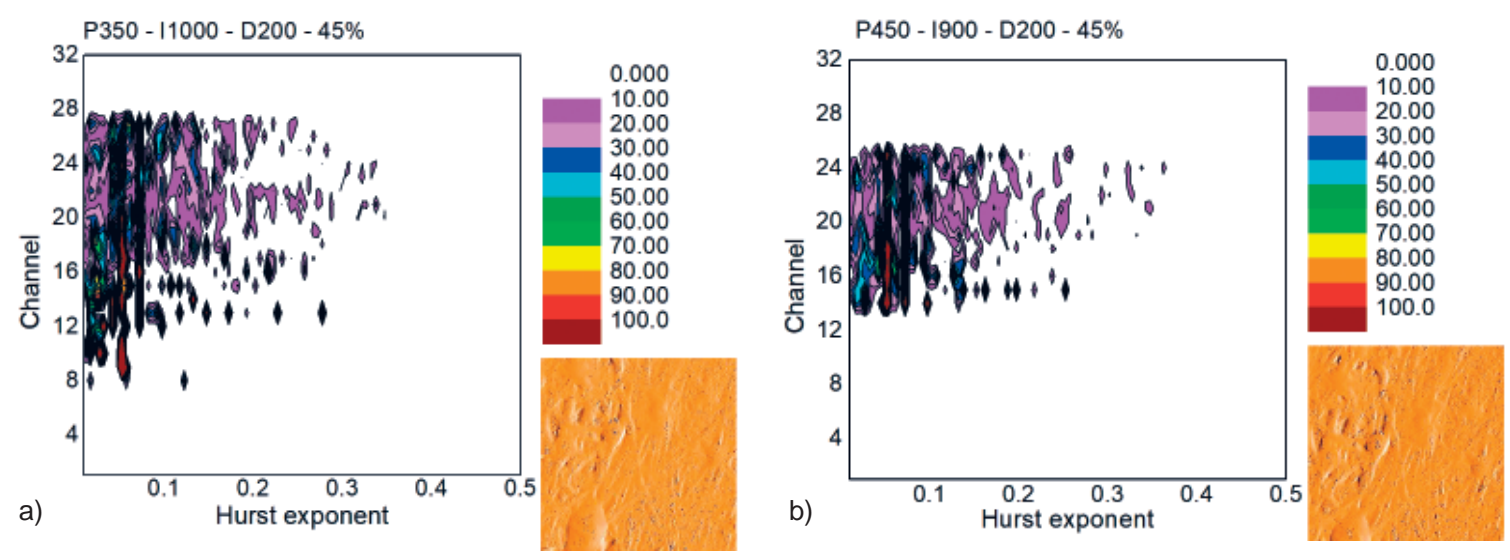

Figure 6: False-colour images of greyscale dependent Hurst exponent distributions obtained through the evaluation of inset AFM images taken with different parameters, as explained in the text. Electrospinning was performed at $80 \mathrm{kV}$, using a nozzle diameter of $0.9 \mathrm{~mm}$ and a polymer solution containing $16 \%$ PAN.

were performed on the amplitude (as used before), phase or z-axis. A comparison of two arbitrarily chosen images is presented in Figure 6.

As visible in this comparison, modifying the control parameters may extend or compress the greyscale range in which information about a sample surface can be found. While this must generally be taken into account, it is nevertheless in both cases possible to distinguish the new image clearly from both images shown in Figure 5 by comparing the greyscale dependent Hurst exponent distributions.

Next, a large set of samples and corresponding Hurst exponent evaluations is necessary to simplify this greyscale dependent evaluation, again without losing necessary information, with the ultimate aim of arriving at a quantitative description of an AFM image using a small set of numbers.

\section{Conclusion and outlook}

Atomic force microscopy images of electrospun nanofibre mats were evaluated for the first time by performing random walks on the fibre areas, as defined in black-and-white images, as well as on full sets of greyscale levels derived from the original images. While the first approach already showed differences between different nanofibre mats, it was insensitive to comparing fibrous and round structures. Much clearer differences between various AFM images were found in the greyscale dependent analysis.

Contrary to common optical microscopic images, AFM images always need settings applied by the user and are thus prone to subjective decisions of the experimenter. In the first tests applied here, Hurst exponent distributions calculated for different settings were found to be highly similar, while this point has to be taken into account during establishing an evaluation routine. In addition, future research is necessary on the impact of the common subsequent image processing step, which is also highly subjective and may cause additional deviations of the results, depending on the experimenter.

\section{References}

1. LIU, Yuyu, DENG, Lingli, ZHANG, Cen, FENG, Fengqin, ZHANG, Hui. Tunable physical properties of ethylcellulose/gelatin composite nanofibers by electrospinning. Journal of Agricultural and Food Chemistry, 2018, 66(8), 1907-1915, doi: 10.1021/acs.jafc.7b06038.

2. BANNER, Jana, DAUTZENBERG, Maria, FELDHANS, Theresa, HOFMANN, Julia, PLÜMER, Pia, EHRMANN, Andrea. Water resistance and morphology of electrospun gelatin blended with citric acid and coconut oil. Tekstilec, 2018, 61(2), 129-135, doi: 10.14502/ Tekstilec2018.61.129-135.

3. DENG, Lingli, ZHANG, Xi, LI, Yang, QUE, Fei, KANG, Xuefan, LIU, Yuyu, FENG, Fengqin, ZHANG, Hui. Characterization of gelatin/zein nanofibers by hybrid electrospinning. Food $\mathrm{Hy}$ drocolloids, 2018, 75, 72-80, doi: 10.1016/j. foodhyd.2017.09.011. 
4. MAVER, Tina, KURECIC, Manja, PIVEC, Tanja, MAVER, Uros, GRADISNIK, Lidija, GASPARIC, Petra, KAKER, Barbara, BRATUSA, Ana, HRIBERNIK, Silvo, STANA KLEINSCHEK, Karin. Needleless electrospun carboxymethyl cellulose/polyethylene oxide mats with medicinal plant extracts for advanced wound care applications. Cellulose, 2020, 27(8), 4487-4508, doi: 10.1007/s10570-020-03079-9.

5. SEDGHI, Roya, SHAABANI, Alireza, SAYYARI, Nastaran. Electrospun triazole-based chitosan nanofibers as a novel scaffold for bone tissue repair and regeneration. Carbohydrate Polymers, 2020, 230, 115707, doi: 10.1016/j.carbpol.2019. 115707.

6. SISAKOVA, K., ORINAK, A., ORINAKOVA, R., STRECKOVA, M., PATERA, J., WELLE, A.; KOSTECKA, Z., GIRMAN, V. Methane decomposition over modified carbon fibers as effective catalysts for hydrogen production. Catalysis Letters, 2020, 150(3), 781-793, doi: 10.1007/ s10562-019-02962-w.

7. FOKIN, Nadine, GROTHE, Timo, MAMUN, Al, TRABELSI, Marah, KLÖCKER, Michaela, SABANTINA, Lilia, DÖPKE, Christoph, BLACHOWICZ, Tomasz, HÜTTEN, Andreas, EHRMANN, Andrea. Magnetic properties of electrospun magnetic nanofiber mats after stabilization and carbonization. Materials, 2020, 13(7), 1552, doi: 10.3390/ma13071552.

8. SHAN, Haoru, SI, Yang, YU, Jianyong, DING, Bin. Flexible, mesoporous, and monodispersed metallic cobalt-embedded inorganic nanofibrous membranes enable ultra-fast and high-efficiency killing of bacteria. Chemical Engineering Journal, 2020, 382, 122909, doi: 10.1016/j. cej.2019.122909.

9. MEHRABI, Pouria, HUI, Justin, JANFAZA, Sajjad, O'BRIAN, Allen, TASNIM, Nishat, NAJJARAN, Homayoun, HOORFAR, Mina. Fabrication of $\mathrm{SnO}_{2}$ composite nanofiber-based gas sensor using the electrospinning method for tetrahydrocannabinol (THC) detection. Micromachines, 2020, 11(2), 190, doi: 10.3390/ mil1020190.

10. BLACHOWICZ, Tomasz, EHRMANN, Andrea. Recent developments in electrospun $\mathrm{ZnO}$ nanofibers: a short review. Journal of Engineered Fibers and Fabrics, 2020, 15, 1558925019899682, doi: 10.1177/1558925019899682.
11. SECUNDINO-SANCHEZ, O., DIAZ-REYES, J., SANCHEZ-RAMIREZ, J. F., MARTINEZ-JUAREZ, J. Stimulation of the photoluminescent properties of electrospinning $\mathrm{TiO}_{2}$ nanofibres induced by structural modifications resulting from annealing at high temperatures. Journal of Luminescence, 2019, 215, 116700, doi: 10.1016/j. jlumin.2019.116700.

12. LIU, Huichao, ZHANG, Shuo, YANG, Jinglong, JI, Muwei, YU, Jiali, WANG, Mingliang, CHAI, Xiaoyan, YANG, Bo, ZU, Caizhen, XU, Jian. Preparation, stabilization and carbonization of a novel polyacrylonitrile-based carbon fiber precursor. Polymers, 2019, 11(7), 1150, doi: 10. 3390/polym11071150.

13. SABANTINA, Lilia, BÖTTJER, Robin, WEHLAGE, Daria, GROTHE, Timo, KLÖCKER, Michaela, GARCÍA MATEOS, José, RODRÍGUEZ-MIRASOL, José, CORDERO, Tomás, EHRMANN, Andrea. Morphological study of stabilization and carbonization of polyacrylonitrile/ $\mathrm{TiO}_{2}$ nanofiber mats. Journal of Engineered Fibers and Fabrics, 2019, 14, 1558925019862242, doi: $10.1177 / 1558925019862242$.

14. GERGIN, Ilknur, ISMAR, Ezgi, SARAC, A. Sezai. Oxidative stabilization of polyacrylonitrile nanofibers and carbon nanofibers containing graphene oxide (GO): a spectroscopic and electrochemical study. Beilstein Journal of Nanotechnology, 2017, 8, 1616-1628, doi: 10.3762/ bjnano.8.161.

15. HECKOVA, M., STRECKOVA, M., ORINAKOVA, R., HOVANCOVA, J.L, GUBOOVA, A., SOPCAK, T., KOVALCIKOVA, A., PLESINGEROVA, B., MEDVED, D., SZABO, J., DUSZA, J. Porous carbon fibers for effective hydrogen evolution. Applied Surface Science, 2020, 506, 144955, doi: 10.1016/j.apsusc.2019.144955.

16. DE OLIVEIRA, Juliana Bovi, MÜLLER GUERRINI, Lilia, CONEJO, Luiza dos Santos, REZENDE, Mirabel Cerqueira, BOTELHO, Edson Cocchieri. Viscoelastic evaluation of epoxy nanocomposite based on carbon nanofiber obtained from electrospinning processing. Polymer Bulletin, 2019, 76(12), 6063-6076, doi: 10. 1007/s00289-019-02707-0.

17. OJEDA-LOPEZ, Reyna, ESPARZA-SCHULZ, J. Marcos, Perez-Hermosillo, Isaac J., HERNANDEZ-GORDILLO, Armin, DOMINGUEZORTIZ, Armando. Improve in $\mathrm{CO}_{2}$ and $\mathrm{CH}_{4}$ 
adsorption capacity on carbon microfibers synthesized by electrospinning of PAN. Fibers, 2019, 7(10), 81, doi: 10.3390/fib7100081.

18. BLACHOWICZ, Tomasz, EHRMANN, Andrea. Conductive electrospun nanofiber mats. Materials, 2020, 13(1), 152, doi: 10.3390/ma13010152.

19. NIKBAKHT, Mohammad, SALEHI, Majid, REZAYAT, Seyed Mahdi, MAJIDI, Reza Faridi. Various parameters in the preparation of chitosan/polyethylene oxide electrospun nanofibers containing Aloe vera extract for medical applications. Nanomedicine Journal, 2020, 7(1), 21-28, doi: 10.22038/nmj.2020.07.03.

20. BIAN, Ye, WANG, Shijie, ZHANG, Li, CHEN, Chun. Influence of fiber diameter, filter thickness, and packing density on PM2.5 removal efficiency of electrospun nanofiber air filters for indoor applications. Building and Environment, 2020, 170, 106628, doi: 10.1016/j.buildenv.2019. 106628.

21. STORCK, Jan Lukas, GROTHE, Timo, MAMUN, Al, SABANTINA, Lilia, KLÖCKER, Michaela, BLACHOWICZ, Tomasz, EHRMANN, Andrea. Orientation of electrospun magnetic nanofibers near conductive areas. Materials, 2020, 13(1), 47, doi: 10.3390/ma13010047.

22. BAZRAFSHAN, Zahra, STYLIOS, George K. Custom-built electrostatics and supplementary bonding in the design of reinforced Collageng-P (methyl methacrylate-co-ethyl acrylate)/ nylon 66 core-shell fibers. Journal of the Mechanical Behavior of Biomedial Materials, 2018, 87, 19-29, doi: 10.1016/j.jmbbm.2018.07.002.

23. CHEN, Yue, QIU, Linlin, MA, Xiangyu, DONG, Lika, JIN, Zhengfei, XIA, Guangbo, DU, Pingfan, XIONG, Jie. Electrospun cellulose polymer nanofiber membrane with flame resistance properties for lithium-ion batteries. Carbohydrate Polymers, 2020, 234, 115907, doi: 10. 1016/j.carbpol.2020.115907.

24. ZHENG, Gaofeng, JIANG, Jiaxin, WANG, Xiang, LI, Wenwang, LIU, Juan, FU, Gang, LIN, Liwei. Nanofiber membranes by multi-jet electrospinning arranged as arc-array with sheath gas for electrodialysis applications. Materials \& Design, 2020, 189, 108504, doi: 10.1016/j.matdes. 2020.108504.

25. GAALOVA, Jana, YALCINKAYA, Fatma, CURINOVA, Petra, KOHOUT, Michal, YALCINKAYA, Baturalp, KOSTEJN, Martin, JIRSAK,
Jan, STIBOR, Ivan, BARA, Jason E., VAN DER BRUGGEN, Bart, IZAK, Pavel. Separation of racemic compound by nanofibrous composite membranes with chiral selector. Journal of Membrane Science, 2020, 596, 117728, doi: 10.1016/j. memsci.2019.117728.

26. YALCINKAYA, Fatma, BOYRAZ, Evren, MARYSKA, Jiri, KUCEROVA, Klara. A review on membrane technology and chemical surface modification for the oily wastewater treatment. Materials, 2020, 13(2), 493, doi: 10.3390/ ma13020493.

27. SRINIVASN, K., DASTOR, P. H., RADHAKRISHNAIAH, P., JAYARAMAN, S. FDAS: a knowledge-based frame detection work for analysis of defects in woven textile structures. The Journal of the Textile Institute, 1992, 83(3), 431-448, doi: 10.1080/00405009208631217.

28. GIORGILLI, Antonio, CASATI, Danilo, SIRONI, Luisella, GALGANI, Luigi. An efficient procedure to compute fractal dimensions by box counting. Physics Letters A, 1986, 115(5), 202-206, doi: 10.1016/0375-9601(86)90465-2.

29. CONCI, Aura, PROENCA, Claudia Belmiro. A fractal image analysis system for fabric inspection system based on box counting method. Computer Networks and ISDN Systems, 1998, 30, 1887-1895, doi: 10.1016/S0169-7552(98)00211-6.

30. BU, Honggang, HUANG, Xiubao. A novel multiple fractal features extraction framework and its application to the detection of fabric defects. The Journal of the Textile Institute, 2008, 99(5), 489-497, doi: 10.1080/00405000701692346.

31. BU, Honggang, WANG, Jun, HUANG, Xiubao. Fabric defects detection based on multiple fractal features and support vector data description. Engineering Applications of Artificial Intelligence, 2009, 22(2), 224-235, doi: 10.1016/j.engappai. 2008.05.006.

32. BLACKMORE, Denis, ZHOU, Jack G. A general fractal distribution function for rough surface profiles. SIAM Journal on Applied Mathematics, 1996, 56(6), 1694-1719, 10.1137/S0036139995283122.

33. YANG, X.Z., PANG, G., YUNG, N. Discriminative fabric defect detection using adaptive wavelet. Optical Engineering, 2002, 41(12), 3116-3126, doi: $10.1117 / 1.1517290$.

34. HANMANDLU, Madau, CHOUDHURY, Dilip, DASH, Sujata. Detection of defects in fabrics using topothesy fractal dimension features. Sig- 
nal Image and Video Processing, 2015, 9(7), 1521-1530; doi: 10.1007/s11760-013-0604-5.

35. PLOTNICK, Roy E., GARDNER, Robert H., HARGROVE, William W., PRESTEGAARD, Karen, PERLMUTTER, Martin. Lacunarity analysis: a general technique for the analysis of spatial patterns. Physical Review E, 1996, 53(5), 5461-5468, doi: 10.1103/PhysRevE.53.5461.

36. CHUN, Hyen Chung, GIMÉNEZ, Daniel, YOON, Sung Won. Morphology, lacunarity and entropy of intra-aggregate pores: aggregate size and soil management effects. Geoderma, 2008, 146(1-2), 83-93, doi: 10.1016/j.geoderma.2008. 05.018.

37. QUAN, Yuhui, XU, Yong, SUN, Yuping, LUO, Yu. Lacunarity analysis on image patterns for texture classification. IEEE Conference on Computer Vision and Pattern Recognition, 2014, 160-167, doi: 10.1109/CVPR.2014.28.

38. DE MELO, R. H. C., CONCI, Aura. Succolarity: defining a method to calculate this fractal measure. 15th International Conference on Systems, Signals and Image Processing, 2008, 10183147, doi: 10.1109/IWSSIP.2008.4604424.

39. VALOUS, Nektarios A., MENDOZA, Fernando, SUN, Da-Wen, \& ALLEN, Paul. Texture appearance characterization of pre-sliced pork ham images using fractal metrics: Fourier analysis dimension and lacunarity. Food Research International, 2009, 42(3), 353-362, doi: 10. 1016/j.foodres.2008.12.012.

40. BLACHOWICZ, Tomasz, EHRMANN, Andrea, DOMINO, Krzysztof. Statistical analysis of digital images of periodic fibrous structures using generalized Hurst exponent distributions. Physica A:
Statistical Mechanics and its Applications, 2016, 452, 167-177, doi: 10.1016/j.physa.2016.02.013.

41. EHRMANN, Andrea, BLACHOWICZ, Tomasz, DOMINO, Krzysztof, AUMANN, Susanne, WEBER, Marcus O., ZGHIDI, Hafed. Examination of hairiness changes due to washing in knitted fabrics using a random walk approach. Textile Research Journal, 2015, 85(20), 2147-2154, doi: 10.1177/0040517515581591.

42. EHRMANN, Andrea, BLACHOWICZ, Tomasz, ZGHIDI, Hafed, WEBER, Marcus O. Reliability of statistic evaluation of microscopic pictures taken from knitted fabrics. Journal of Physics: Conference Series, 2015, 633, 012101, doi: 10. 1088/1742-6596/633/1/012101.

43. LI, Jing, TENG, Honglei, LIU, Suqing, XU, Jing, LI, Tianduo. Three-dimensional spatial distribution analysis of fibre in wet-blue pig leather. Journal of the Society of Leather Technologists and Chemists, 2018, 102(3), 111-117.

44. EHRMANN, Andrea, BLACHOWICZ, Tomasz. Angle and rotational direction dependent horizontal loop shift in epitaxial $\mathrm{Co} / \mathrm{CoO}$ bilayers on $\mathrm{MgO}(100)$. AIP Advances, 2017, 7(11), 115223, doi: 10.1063/1.4985032.

45. BLACHOWICZ, Tomasz, KOSMALSKA, Dorota, DÖPKE, Christoph, LEISTE, Harald, HAHN, Lothar, EHRMANN, Andrea. Varying steps in hysteresis loops of Co square nano-frames. Journal of Magnetism and Magnetic Materials, 2019, 491, 165619, doi: j.jmmm.2019.165619.

46. HAVLIN, Shlomo; BEN-AVRAHAM, Daniel. Diffusion in disordered media. Advances in physics, 2002, 51(1), 187-292, doi: 10.1080/ 00018730110116353. 